\title{
KEARIFAN LOKAL SUNDA DALAM PEMANFAATAN TANAMAN BERKHASIAT OBAT OLEH MASYARAKAT CIPATAT KABUPATEN BANDUNG BARAT
}

\author{
Santi Susanti, Sukaesih \\ Fakultas Ilmu Komunikasi Universitas Padjadjaran \\ santisusanti2202@gmail.com \\ Diajukan: 24-11-2017; Direview: 24-11-2017; Diterima: 23-12-2017;
}

\begin{abstract}
Indonesia's biodiversity provides many benefits for the inhabitants of the archipelago, one of them as medicine. This study aims to reveal the local wisdom in the utilization of medicinal plants by villagers of Sumur Bandung and Gunung Masigit, Cipatat District, Bandung Barat Regency. Using qualitative method with phenomenological approach, data collected through interview, observation, and literature study. The results of the study found that the utilization of herbal medicine by villagers of Sumur Bandung and Gunung Masigit Village is the inheritance of their ancestors. They used plants that categorized as medicinal plants and vegetables which have a healing elements. Knowledge of planting and cultivating efficacy is obtained from a variety of sources and knowledge is passed on to the next generation. This study concluded that the utilization of medicinal plants is a form of local wisdom in utilizing natural resources as a source of food and as a healer.
\end{abstract}

Keywords: local wisdom, medicinal plants, health literacy

\begin{abstract}
Abstrak
Keanekaragaman hayati Indonesia memberikan banyak manfaat bagi penduduk nusantara, salah satunya sebagai obat. Penelitian ini bertujuan untuk mengungkap kearifan lokal dalam pemanfaatan tanaman berkhasiat obat oleh masyarakat Desa Sumur Bandung dan Desa Gunung Masigit, Kecamatan Cipatat, Kabupaten Bandung Barat. Menggunakan metode kualitatif dengan pendekatan fenomenologi, data dikumpulkan melalui wawancara, observasi, dan studi pustaka. Hasil penelitian menemukan, pemanfaatan tanaman berkhasiat oleh masyarakat Desa Sumur Bandung dan Desa Gunung Masigit merupakan warisan dari leluhurnya. Tumbuhan yang dimanfaatkan tidak hanya yang dikategorikan tanaman obat, juga sayuran yang memiliki khasiat menyembuhkan. Pengetahuan cara menanam dan khasiat tanaman diperoleh dari beragam sumber dan pengetahuan tersebut diwariskan kepada generasi selanjutnya. Kesimpulan dari penelitian ini, pemanfaatan tanaman berkhasiat obat merupakan bentuk kearifan lokal dalam memanfaatkan sumber daya alam yang tersedia sebagai sumber pangan dan sebagai penyembuh.
\end{abstract}

Kata kunci: kearifan lokal, tanaman berkhasiat obat, literasi kesehatan

\section{PENDAHULUAN}

I ndonesia merupakan negara yang memiliki keanekaragaman hayati yang tinggi. Sekira 30 ribu jenis dari 40 ribu jenis tumbuhan yang ada di dunia, ada di Indonesia. Bahkan 80 persen tanaman obat yang ada di dunia,tumbuh di Indonesia. Dari 28.000 spesies tanaman yang tumbuh, 1.000 spesies di antaranya telah digunakan sebagai tanaman obat (Pramono dalam Pribadi, 2009). Keanekaragaman hayati tersebut telah lama dimanfaatkan oleh masyarakat Indonesia untuk pengobatan secara tradisional. Dengan pengetahuan dan kearifan lokal yang dimiliki secara turun temurun dari leluhurnya, masyarakat Indonesia memanfaatkan tumbuhan untuk meredakan gejala hingga menyembuhkan beragam penyakit yang dideritanya. Ada yang langsung dimanfaatkan, ada juga yang harus diracik dengan tanaman obat lainnya. Bahan-bahan yang dijadikan ramuan, diambil dari bagian akar, daun, bunga, buah maupun kayunya (Suparni,2012: 3). 
Pemanfaatan tanaman sebagai obat merupakan bagian dari strategi masyarakat Sunda dalam memenuhi kebutuhan mereka untuk mengatasi persoalan yang terkait dengan kesehatan. Strategi tersebut merupakan bagian dari budaya masyarakat tertentu yang dikenal dengan kearifan lokal. Dalam konteks penelitian ini, budaya yang dimaksud adalah budaya lokal masyarakat Sunda dalam hubungannya dengan alam. Hal ini sebagaimana dikemukakan oleh Fajarini (2014:123-124), yang mengartikan kearifan lokal sebagai pandangan hidup dan ilmu pengetahuan serta berbagai strategi kehidupan yang berwujud aktivitas yang dilakukan oleh masyarakat lokal dalam menjawab berbagai masalah dalam pemenuhan kebutuhan mereka. Kearifan masyarakat lokal dalam menjalin hubungan dengan alam, umumya diidentikkan dengan wilayah pedesaan, yang memiliki kawasan hayati cukup luas. Masyarakat di kawasan tersebut masih banyak yang bekerja sebagai petani yang menggarap di lahan khusus serta menjadikan lahan pekarangan mereka sebagai tempat untuk menanam tumbuhan yang ditujukan untuk kepentingan mereka, di antaranya menanam tanaman berkhasiat obat. Di kawasan Kabupaten Bandung Barat, sebagian besar masyarakatnya masih berprofesi sebagai petani dan masih ada yang memanfaatkan tanaman berkhasiat obat sebagai penyembuh dari keluhan kesehatan yang dideritanya. Penelusuran awal dokumentasi hasil penelitian yang diperoleh dari internet menemukan, wilayah di Kabupaten Bandung Barat yang penduduknya masih memanfaatkan tanaman sebagai obat adalah Desa Gunung Masigit dan Desa Sumur Bandung, yang terdapat di Kecamatan Cipatat, kecamatan terluas dari 16 kecamatan yang berada di wilayah Kabupaten Bandung Barat.

Dari penjelasan tersebut, dapat diketahui bahwa sebelum obat-obatan modern berkembang, atas dasar kearifan lokal, masyarakat Indonesia terlebih dulu memanfaatkan tumbuhan di sekitarnya sebagai obat. Meskipun produk obat-obatan sudah berkembang, namun, masih saja ada masyarakat yang tetap memelihara kearifan lokal dengan memanfaatkan tanaman obat sebagai penyembuh atas penyakit yang dideritanya. Atas dasar tersebut, maka penelitian ini dirumuskan pada pertanyaan
"Bagaimana pengalaman masyarakat Kecamatan Cipatat memanfaatkan tumbuhan sebagai obat?". Adapun tujuan penelitian ini yakni mengungkap pengalaman pemanfaatan tanaman berkhasiat obat oleh masyarakat Desa Gunung Masigit dan Desa Sumur Bandung, Kabupaten Bandung Barat, bagaimana cara penduduk memeroleh pengetahuan mengenai tanaman berkhasiat obat serta mengungkap kearifan lokal yang terkandung dalam aktivitas pemanfaatan tumbuhan berkhasiat obat.

\section{LITERATUR DAN METODOLOGI}

Dalam penelitian ini, peneliti mengkaji 3 karya ilmiah yang meneliti dan mengkaji tentang kearifan lokal dalam pemanfaatan pengobatan tradisional menggunakan tanaman berkhasiat obat. Ketiga artikel ilmiah tersebut berjudul Masyarakat Baduy dan Pengobatan Tradisional Berbasis Tanaman karya R. Cecep Eka Permana, Kajian Etnobotani Tumbuhan Obat oleh Masyarakat di Desa Gunung Masigit Kecamatan Cipatat Kabupaten Bandung Barat, dan Eksplorasi Pengetahuan Lokal tentang Tumbuhan Obat di Suku Batin, Jambi, karya Julius dan Muswita dari Universitas Jambi.

Pada artikel pertama, peneliti menggambarkan mengenai keteguhan masyarakat Baduy dalam melestarikan budaya nenek moyang untuk tetap memanfaatkan tanaman obat sebagai pengobatan tradisional dan menghindari pengobatan secara modern, meskipun dalam praktiknya, hal tersebut menimbulkan dilema dalam diri mereka, antara memperoleh kesehatan modern dengan tetap mempertahankan adat tradisi. Dalam tulisan ini, masyarakat Desa Gunung Masigit dan Desa Sumur Bandung, bukanlah masyarakat yang terikat dengan adat sehingga warga bebas menentukan metode pengobatan yang ingin mereka lakukan, apakah modern atau tradisional.

Pada artikel kedua, peneliti menginventarisir jenis-jenis tumbuhan obat yang yang dimanfaatkan masyarakat Desa Gunung Masigit Kabupaten Bandung Barat. Tujuan penelitian tersebut adalah untuk mendapatkan informasi tumbuhan obat yang digunakan masyarakat Desa Gunung Masigit, serta untuk mengetahui jenis tanaman obat tradisional, mengetahui bagian tanaman yang dimanfaatkan 
sebagai obat tradisional dan manfaat tanaman obat yang dimanfaatkan oleh masyarakat Desa Gunung Masigit Kabupaten Bandung Barat. Dalam tulisan ini, penulis tidak berupaya untuk menginventarisir jenis tumbuhan obat dan cara pemanfaatannya secara teknis, melainkan mencari informasi mengenai pengalaman warga Desa Gunung Masigit dan Desa Sumur Bandung dalam memanfaatkan khasiat tanaman obat dalam mengatasi gangguan kesehatan.

Penelitian pada artikel ketiga bertujuan menginventarisasi pemanfaatan tumbuhan obat berdasarkan gejala penyakitnya. Melalui metode survei pada 5 Battra (dukun) di kecamatan Tabir, Kabupaten Merangin, Jambi, hasilnya menemukan 86 jenis tumbuhan obat digunakan oleh masyarakat Suku Batin untuk berbagai pengobatan. Kemampuan untuk menggunakan ramuan ini diperoleh secara turun-temurun. Pada umumnya tanaman obat masih diperoleh secara liar seperti di tepi sungai dan hutan, sebagian tanaman obat telah mulai dibudidayakan di pekarangan rumah. Dalam tulisan ini, subjek atau informan penelitiannya adalah warga Desa Gunung Masigit dan Desa Sumur Bandung yang masih memanfaatkan dan menanam tanaman berkhasiat obat di lahan kebun atau pekarangan rumah mereka untuk keperluan pribadi atau sebagai persediaan jika ada yang membutuhkan.

Penelitian ini menggunakan metode kualitatif fenomenologis, untuk menghimpun dan mengungkapkan pengalaman para informan menerapkan kearifan lokal dalam memanfaatkan tanaman sebagai obat. Pengalaman digambarkan sesuai dengan fakta-fakta yang diperoleh di lapangan sesuai penyampaian dari informan. Subjek penelitian ini adalah warga masyarakat Desa Gunung Masigit dan Desa Sumur Bandung, yang masih memanfaatkan tanaman sebagai obat. Sampel penelitian ini dipilih berdasarkan tujuan atau purposive sampling. Pengumpulan data dilakukan melalui wawancara, observasi, dan studi pustaka. Sumber data dari penelitian ini adalah para tokoh masyarakat serta warga yang masih intensif memanfaatkan tanaman obat untuk mengatasi beragam keluhan kesehatan mereka. Sumber data sekunder berasal dari buku, jurnal, majalah, dan artikel yang membahas tentang pemanfaatan tanaman obat. Data yang diperoleh diolah dan dianalisis sesuai dengan konteks hasil yang ditemukan dan hasilnya disampaikan secara deskriptif ke dalam kalimat-kalimat menjelaskan penemuan penelitian sesuai konteksnya.

Tanaman obat adalah tanaman yang salah satu, beberapa atau seluruh bagian tanaman tersebut mengandung zat atau bahan aktif yang berkhasiat bagi kesehatan. Bagian tanaman yang dimaksud adalah daun, bunga, buah, kulit buah, kulit batang, batang, akar dan umbi. (Rahardi, 1996: 3). Menurut Zaman (2009: 20), tumbuhan obat adalah tumbuhan yang dapat dipergunakan sebagai obat baik yang sengaja ditanam maupun yang tumbuh secara liar. Tumbuhan tersebut dimanfaatkan oleh masyarakat untuk diramu dan disajikan sebagai obat guna penyembuhan penyakit. Kartika (2015) mendefinisikan tumbuhan obat sebagai tumbuhan berkhasiat obat yang dapat menghilangkan rasa sakit, meningkatkan daya tahan tubuh, membunuh bibit penyakit dan memperbaiki organ yang rusak. Tumbuhan obat terdiri dari beberapa macam habitus, yaitu gambaran penampilan umum atau arsitektur suatu tumbuhan. Menurut Tjitrosoepomo (2005: 12) habitus dari spesies tumbuhan dapat dibagi kedalam beberapa kelompok, yaitu: Herba adalah tumbuhan yang tak berkayu dengan batang yang lunak dan berair.; Pohon adalah tumbuhan yang tinggi besar, batang berkayu dan bercabang jauh dari permukaan tanah.; Semak adalah tumbuhan yang tak seberapa besar, batang berkayu, bercabang- cabang dekat permukaan tanah atau malahan dalam tanah.; Perdu adalah tumbuhan berkayu yang tidak seberapa besar dan bercabang dekat dengan permukaan, biasanya kurang dari 5-6 meter.; Liana adalah tumbuhan berkayu dengan batang menjulur/memanjat pada tumbuhan lain.

Tradisi mengonsumsi ramuan dari tanaman obat untuk berbagai tujuan telah dilakukan oleh nenek moyang terdahulu. Salah satu tujuannya adalah mengobati, baik untuk diri sendiri maupun untuk orang lain. Hal ini menunjukan bahwa pengobatan tradisional menggunakan tanaman obat sudah menjadi budaya dan sangat nyata kontribusinya dalam menyehatkan masyarakat. 
Oleh karena itu, ramuan dari tanaman obat bersifat konstruktif, efektif, aman dan relatif murah, sehingga keberadaan ramuan tersebut akan sangat dibutuhkan sampai kapan pun. Ramuan obat tradisional dipercaya dapat memberikan penyembuhan bagi penyakit yang hampir tidak bisa disembuhkan. Selain itu, terdapat beberapa bukti yang menunjukan bahwa tanaman dijadikan obat karena memiliki kandungan kimia yang memiliki efek farmakologis (Adi, 2006: 11) antara lain: Meningkatkan kekebalan tubuh. Tanaman obat tertentu dapat berfungsi untuk meningkatkan kekebalan tubuh dari serangan virus penyakit seperti bawang putih, lidah buaya, meniran, dan kayu manis.; Tonikum, untuk pemulihan serta peningkatan kesehatan, misalnya dengan memanfatkan tanaman obat seperti jahe merah, gingseng, tapak lima, dan sambiloto.; Antikanker. Proses pencegahan dan penyembuhan kanker dapat dilakukan dengan mengkonsumsi tanaman obat seperi teh hijau, tapak dara, benalu, dan jamur lingzhi.; Mencegah penuaan dini, misalnya dengan memanfaatkan mengkudu, pegagan, dan jinten hitam.; Mengurangi rasa sakit (analgesik). Tanaman obat yang dapat mengurangi atau menghilangkan rasa nyeri yaitu tanaman obat seperti serai, brotowali, dan bidara upas.; Anti radang akibat rematik dan asam urat, seperti cabai merah, kunyit, lada, dan gandapura.

Penggunaan tanaman obat di seluruh dunia sudah dikenal sejak beribu-ribu tahun yang lalu. Termasuk di Indonesia. Penggunaan tanaman obat di Indonesia juga telah berlangsung ribuan tahun yang lalu. Pada pertengahan abad XVII, seorang botanikus bernama Jacobus Rontius (1592-1631) memublikasikan manfaat dan khasiat tumbuhan dalam De Indiae Untriusquere Naturali et Medica. Pada tahun 1888 didirikan Chemis PharmacologischLaboratorium sebagaibagian dari Kebun Raya Bogor. Tujuannya untuk menyelidiki bahan-bahan atau zat-zat yang terdapat dalam tumbuh-tumbuhan yang dapat digunakan untuk obat-obatan. Sejak itulah, penelitian dan publikasi mengenai khasiat tanaman obat-obatan di Indonesia semakin berkembang (Suparni dan Wulandari 2012: 4).

Secara etimologis, kearifan lokal terdiri dari dua kata yaitu kearifan (wisdom) dan lokal (local). Pada KBBI, lokal berarti setempat, sedangkan kearifan sama dengan kebijaksanaan. Sehingga jika dilihat secara etimologis, kearifan lokal (local wisdom) dapat diartikan sebagai gagasan-gagasan setempat (lokal) yang bersifat bijaksana, penuh kearifan, bernilai baik, yang tertanam dan diikuti oleh anggota masyarakatnya. Pengertian kearifan lokal yang lain dikemukakan oleh Suhartini (2009) yang menyatakan bahwa kearifan lokal merupakan suatu bentuk kearifan lingkungan yang ada dalam kehidupan bermasyarakat di suatu tempat atau daerah yang merujuk pada lokalitas dan komunitas tertentu.

\section{TEMUAN DAN DISKUSI}

Penelitian ini dilakukan di dua desa di Kecamatan Cipatat, yaitu Desa Gunung Masigit dan Desa Sumur Bandung. Pemilihan dua lokasi tersebut didasarkan pada pertimbangan, bahwa masih banyak penduduk yang memanfaatkan lahan untuk pertanian, yang beberapa di antaranya yang ditanam merupakan tumbuhan yang memiliki khasiat obat. Selain itu, berdasarkan pengamatan yang dilakukan di kawasan tersebut sebelum penelitian inti dilakukan, di pekarangan rumah warga banyak ditanam tumbuhan yang memiliki khasiat obat dan dimanfaatkan untuk kepentingan sendiri maupun warga sekitarnya. Perilaku warga Desa Gunung Masigit dan Desa Sumur Bandung dalam memanfaatkan tanaman sebagai obat, dilakukan sejak lama dan merupakan warisan turun-temurun dari leluhur mereka. Bagi warga kecamatan Cipatat, khususnya di Desa Gunung Masigit dan Sumur Bandung, menanam tumbuhan berkhasiat obat telah menjadi bagian dari kehidupan mereka, yang sebagian besar berprofesi sebagai petani. Tanaman tersebut ada yang ditanam di pekarangan, ada juga yang ditanam di kebun. Untuk yang ditanam di kebun, biasanya merupakan komoditi pertanian yang bisa dijual ke pasar, seperti jahe, kunyit, laja, pala, muncang, bawang daun, sereh, bawang merah, dan sebagainya. Sementara untuk yang ditanam di pekarangan rumah, biasanya dipergunakan untuk kebutuhan dapur dan untuk pengobatan pertolongan pertama.

Hampir semua bagian tumbuhan berkhasiat 
obat bisa dimanfaatkan sebagai penyembuh. Cara pemanfaatannya dilakukan secara beragam, ada yang direbus, dikunyah, diparut untuk diambil sarinya, dikukus, atau diracik dengan media lain. Menurut para informan, sifat pengobatan dari tumbuhan-tumbuhan hanya sementara, sebagai pertolongan pertama, andaikata timbul rasa sakit. Umumnya, gangguan kesehatan yang bisa ditangani dengan tanaman berkhasiat obat adalah yang kadarnya tidak berat, misalnya masuk angin, bengkak, digigit serangga, pusing kepala, sakit perut, dan sebagainya. Untuk yang memerlukan penanganan lebih dari sekadar minum obat, biasanya langsung dibawa ke dokter atau ke rumah sakit. Pengetahuan informan mengenai khasiat tanaman obat diperoleh melalui berbagai sumber. Warga memanfaatkan kemampuan literasinya untuk mengatasi persoalan kesehatan dalam dirinya.. Tompkins (1991:18) mengemukakan bahwa literasi merupakan kemampuan menggunakan membaca dan menulis dalam melaksanakan tugas-tugas yang bertalian dengan dunia kerja dan kehidupan di luar sekolah. Menurut Unesco, seseorang disebut literate apabila ia memiliki pengetahuan yang hakiki untuk digunakan dalam setiap aktivitas yang menuntut fungsi literasi secara efektif dalam masyarakat dan pengetahuan yang dicapainya dengan membaca, menulis, aritemetik, memungkinkan untuk dimanfaatkan bagi dirinya sendiri dan perkembangan masyarakat. (Anggraini, 2016: 264-265)

Ada yang diperoleh secara turun temurun dari leluhur pihak keluarga, ada juga yang melalui interaksi dengan warga masyarakat sekitar/tetangga/ saudara atau melihat tayangan di televisi atau buku-buku mengenai khasiat tanaman untuk obat-obatan. Umumnya, bagi yang diperoleh secara turun temurun dari leluhur, proses perolehan pengetahuan tersebut tidak sengaja dilakukan. Proses transfer informasi mengenai khasiat dari tumbuhan untuk pengobatan dilakukan ketika keluhan dirasakan. Orang tua yang mengetahui mengenai manfaat tumbuhan secara spontan menginformasikan untuk mencari tanaman yang bisa menyembuhkan penyakit yang diderita. Demikian pula ketika berinteraksi dengan tetangga, kerabat atau saudara. Proses transfer informasinya dilakukan secara spontan pada saat keluhan dirasakan. Sementara itu, pemerolehan pengetahuan yang sengaja dilakukan diperoleh melalui tayangan televisi atau mencari informasi melalui buku. Sementara bagi warga desa yang tergabung dalam kelompok tani, pengetahuan mengenai tanaman pertanian dan tanaman berkhasiat obat diberikan oleh penyuluh pertanian dari dinas maupun dari instansi pertanian dalam suatu riungan yang sengaja dilakukan untuk menambah pengetahuan mengenai cara menanam yang baik.

Selain itu, warga pun melakukan pembibitan untuk mendapatkan benih tumbuhan yang akan mereka tanam di kebun. Pembibitan dilakukan sesuai dengan kebutuhan waktunya disesuaikan dengan musim tanam. Meski pergeseran penggunaan lahan telah terjadi, karena banyak lahan pertanian yang digunakan untuk menanam menanam singkong dan pisang, namun, warga yang menanam tanaman pertanian pun masih banyak. Lahan kebun yang tersedia masih dimanfaatkan untuk menanam sayuran juga menanam tumbuhan yang berkhasiat obat. Berdasarkan pengamatan yang dilakukan di lokasi penelitian, banyak warga yang memanfaatkan lahan pekarangan mereka untuk menanam tanaman yang bisa dimanfaatkan untuk keperluan pribadi, antara lain sereh, daun bawang, paria, cabe rawit, kelapa kuning, dan lainnya. Tanaman tersebut, selain dapat digunakan untuk keperluan dapur, juga untuk pengobatan, baik untuk keluarga maupun dibagikan jika ada yang membutuhkan.

Beberapa jenis tanaman dan sayuran yang dijadikan obat oleh warga Desa Gunung Masigit dan Desa Sumur Bandung antara lain jahe, kunyit, laja, kelapa kuning, kelapa hijau daun jawer kotok, kumis kucing, paria, sambiloto, daun singkong, daun pepaya, daun pisang, labu, dan lainnya. Pemanfaatannya misalnya untuk sakit perut, tangan teriris pisau, demam, sakit gigi, penyakit kuning, dll. Pengetahuan mengenai khasiat obat yang terkandung dalam tanaman pun tidak disimpan sendiri, melainkan ditularkan pula ke orang-orang di sekelilingnya. Beragam cara dilakukan dalam mentransfer pengetahuan tersebut. Ada yang dilakukan melalui interaksi langsung ketika ada 
warga yang mengeluhkan sakit, ada pula yang dilakukan melalui penyuluhan yang dilakukan di lingkungan warga. Penyampaian pengetahuan tersebut dilakukan oleh individu-individu yang terpilih sebagai kader desa maupun sebagai ketua kelompok tani. Ada juga dengan mendatangkan penyuluh pertanian dari dinas maupun lembaga pengembangan pertanian.

HG. Quaritch Wales (dalam Budiwiyanto 2005: 25) menyebut kearifan lokal sebagai local genius yang berarti sejumlah ciri kebudayaan yang dimiliki bersama oleh suatu masyarakat sebagai suatu akibat pengalamannya di masa lalu. Negara (2011) menyatakan bahwa kearifan lokal bukan hanya menyangkut pengetahuan atau pemahaman masyarakat adat/lokal tentang manusiadan bagaimana relasi yang baik diantara manusia, melainkan juga menyangkut pengetahuan, pemahaman, dan adat kebiasaan tentang manusia, alam, dan bagaimana relasi diantara semua, dimana seluruh pengetahuan itu dihayati, dipraktikkan, diajarkan, dan diwariskan dari satu generasi ke generasi. Bentuk-bentuk kearifan lokal yang ada di masyarakat menurut Aulia dan Dharmawan (2010) dapat berupa nilai, norma, kepercayaan, dan aturan-aturan khusus. Bentuk yang bermacam-macam ini mengakibatkan fungsi kearifan lokal menjadi bermacam-macam pula. Fungsi kearifan lokal tersebut antara lain untuk: (1) konservasi dan pelestarian sumber daya alam; (2) mengembangkan sumberdaya manusia; (3) pengembangan kebudayaan dan ilmu pengetahuan; serta (4) petunjuk tentang petuah, kepercayaan, sastra, dan pantangan.

Hadi (2006) mengatakan bahwa kearifan lokal dipandang sangat bernilai dan mempunyai manfaat tersendiri dalam kehidupan masyarakat, setidaknya bagi masyarakat pemiliknya. Sistem tersebut dikembangkan karena adanya kebutuhan untuk menghayati, mempertahankan, dan melangsungkan hidup sesuai dengan situasi, kondisi, kemampuan, dan tata nilai yang dihayati di dalam masyarakat terkait. Dengan kata lain, kearifan lokal tersebut kemudian menjadi bagian dari cara hidup mereka yang arif, untuk memecahkan segala permasalahan hidup yang mereka hadapi. Berkat kearifan lokal itu, mereka dapat melangsungkan kehidupannya, bahkan dapat berkembang secara berkelanjutan. Pengetahuan tradisional dan kearifan lokal itu antara lain mencakup pengobatan berbasis tanaman atau tumbuhan. Hidayat dalam bukunya Ramuan tradisional ala 12 etnis Indonesia mengisahkan bahwa tumbuh-tumbuhan telah digunakan oleh manusia sejak beribu tahun yang lalu untuk menjaga kesehatan dan mengobati berbagai penyakit. (Permana, 2009: 84)

Dalam buku Tumbuhan Obat Indonesia: Penggunaan dan Khasiatnya, yang disusun oleh Supriadi dkk., dinyatakan bahwa pengetahuan lokal dalam pemanfaatan tumbuhan/bahan alami untuk pengobatan umumnya dimiliki oleh masyarakat yang terutama berada di sekitar kawasan hutan. Pengetahuan tentang tumbuhan obat, mulai dari pengenalan jenis tumbuhan, bagian yang digunakan, cara pengolahan sampai dengan khasiat pengobatannya, merupakan kekayaan pengetahuan lokal dari masing- masing etnis dalam masyarakat setempat tersebut. Pengetahuan masyarakat tradisional tentang khasiat obat suatu tumbuhan untuk penyembuhan suatu penyakit pada umumnya didasarkan pada isyarat alam atau perilaku binatang. Sebagai contoh, helai daun yang berbentuk hati mempunyai petunjuk dapat menyembuhkan penyakit hati; bagian tanaman yang berwarna kuning seperti kunyit dan temulawak mempunyai petunjuk dapat menyembuhkan penyakit kuning; binatang sakit yang makan jenis tumbuhan tertentu memberi petunjuk bahwa tumbuhan tersebut berkhasiat obat (Supriadi dkk. 2001: ix-xi).

Pada masyarakat Desa Gunung Masigit dan Desa Sumur Bandung, kearifan lokal yang berkaitan dengan tumbuhan berkhasiat obat tersebut adalah pemanfaatan lahan yang tersedia untuk dioptimalkan sehingga tidak menjadi lahan yang mati dan sia-sia. Menurut warga, manfaat yang diperoleh dengan menanam di pekarangan adalah kemudahan untuk memperoleh bahanbahan yang dibutuhkan untuk memasak. Mereka tidak perlu keluar lingkungan rumah untuk membeli beberapa bahan masakan seperti jahe, lengkuas, kunyit, kencur atau cabe rawit. Mereka tinggal melangkah ke pekarangan, bahan yang dibutuhkan tinggal dibawa. Dana yang keluar pun 
lebih hemat. Selain itu dengan menjadi petani, lahan yang tersedia dapat dimanfaatkan dan hasilnya pun tidak hanya dimanfaatkan untuk diri sendiri, juga bisa dijual sehingga menghasilkan uang yang bisa dimanfaatkan untuk berbagai keperluan. Selain itu, tanah pun dapat terjaga kesuburannya. Dengan memanfaatkan lahan yang tersedia, baik di kebun maupun di pekarangan, warga Desa Gunung Masigit dan Desa Sumur Bandung, Kecamatan Cipatat, Kabupaten Bandung Barat, telah melakukan kearifan lokal dengan menjaga kelestarian alam dengan mengolah tanah agar tetap subur dan dapat ditanami tumbuhan. Dengan demikian, salah satu kearifan lokal yang berhubungan dengan alam dapat terjaga dengan baik.

\section{SIMPULAN}

Pemanfaatan lahan oleh warga Desa Gunung Masigit dan Desa Sumur Bandung, Kecamatan Cipatat, untuk ditanami tumbuhan berkhasiat obat merupakan bagian dari aktifitas mereka sebagai masyarakat yang hidup di kawasan pedesaan dengan lahan luas yang bisa dimanfaatkan untuk pertanian. Selain itu, mereka juga memelihara warisan leluhur untuk menanam tanaman yang berkhasiat obat, baik tanaman yang dikategorikan tanaman obat, maupun tanaman pertanian yang berkhasiat obat. Kegiatan menanam tersebut, selain untuk tanaman obat, juga dimanfaatkan untuk kebutuhan sendiri misalnya untuk memasak, atau untuk persediaan jika ada kerabat atau tetangga yang membutuhkan. Tumbuhan berkhasiat obat tersebut, digunakan sebagai pertolongan pertama jika ada anggota keluarga atau warga yang didera sakit, karena letak apotik dan rumah sakit jauh. Tanaman berkhasiat obat yang masuk kategori sayuran, juga dijual untuk memenuhi kebutuhan ekonomi keluarga.

Pemerolehan pengetahuan mengenai tanaman berkhasiat obat diperoleh secara tidak disengaja dan disengaja. Secara tidak sengaja, pengetahuan tersebut diperoleh melalui interaksi sosial, yakni ketika keluhan dirasakan, maka, orang yang memiliki pengetahuan tentang tumbuhan obat akan menginformasikan tanaman yang harus didapatkan untuk menyembuhkan gejala penyakit yang dirasakan. Sementara itu, pemerolehan pengetahuan secara sengaja dilakukan melalui penyuluhan yang dilakukan oleh penyuluh pertanian dari instansi pemerintah maupun dari lembaga pengembangan pertanian. Kegiatan ini umumnya dilakukan di lingkungan kelompok tani. Sementara itu, kearifan lokal yang tergambar dari hasil penelitian ini adalah pemanfaatan lahan yang optimal di pekarangan maupun di kebun untuk ditanami tumbuhan berkhasiat obat maupun tanaman pertanian yang digunakan untuk kepentingan pribadi maupun untuk didistribusikan/ dijual ke pasar induk. Dengan memanfaatkan lahan yang tersedia, baik di kebun maupun di pekarangan, warga Desa Gunung Masigit dan Desa Sumur Bandung, Kecamatan Cipatat, Kabupaten Bandung Barat, telah melakukan kearifan lokal dengan menjaga kelestarian alam dengan mengolah tanah agar tetap subur dan dapat ditanami tumbuhan.

Saran yang dapat disampaikan dari hasil penelitian ini adalah budi daya tanaman berkhasiat obat harus dikembangkan lagi, karena bibitnya sudah mulai langka dan warga masih banyak yang belum paham mengenai khasiat tanaman untuk obat. Banyak warga yang masih memerlukan penyuluhan mengenai pengelolaan lahan yang baik, agar penanaman tumbuhan maupun sayuran berkhasiat obat dapat berkelanjutan. Selain penyuluhan, pembibitan pun harus dilakukan dan hal tersebut memerlukan perhatian pemerintah, terutama dalam pemberian pupuk, pengolahan pertanian, serta pemberian dana pinjaman dan sumbangan barang dan peralatan teknik pertanian.

\section{DAFTAR PUSTAKA}

Anggraini, Siti. 2016. Budaya Literasi dalam Komunikasi. Wacana Jurnal Ilmiah Ilmu Komunikasi Volume XV No.3 (September 2016), 181-279

Aulia,T.O.S; A.H., Dharmawan. 2010. Kearifan Lokal dalam Pengelolaan Sumberdaya Air di Kampung Kuta. Sodality: Jurnal Transdisiplin Sosiologi, Komunikasi, dan Ekologi Manusia.4 (3):345-355.

Budiwiyanto, J. 2005. Tinjauan Tentang 
Perkembangan Pengaruh Local Genius dalam Seni Bangunan Sakral (Keagamaan) di Indonesia. Ornamen 2 (1) : 24-35.

Fajarini, U. 2014. Peranan Kearifan Lokal dalam Pendidikan Karakter. Sosio Didaktika 1(2): 123-130.

Hadi, A.C Sungkana. 2006. Melestarikan kearifan masyarakat tradisional (Indigenous Knowledge), Buletin Perpustakaan dan Informasi Bogor (Juni): 27-32.

Hidayat, Syamsul. 2005. Ramuan tradisional ala 12 etnis Indonesia. Jakarta: Penebar Swadaya.

Jalius dan Muswita. Eksplorasi Pengetahuan Lokal tentang Tumbuhan Obat di Suku Batin, Jambi online-journal.unja.ac.id , Home > Vol 6, No 1 (2013) > Jalius

Kartika, T. 2015. Inventarisasi Jenis-jenis Tumbuhan Berkhasiat Obat di desa Tanjung Baru Petai Kecamatan Tanjung Batu Kabupaten Ogan Ilir (OI) Provinsi Sumatera Selatan. Sainmatika. 12(1): 3241.

Negara, P.D. 2011. Rekonstruksi Kebijakan Pengelolaan Kawasan Konservasi Berbasis Kearifan Lokal sebagai Kontribusi Menuju Pengelolaan Sumber Daya Alam yang Indonesia. Jurnal Konstitusi.IV(2):91-138.

Permana, R. Cecep Eka. Masyarakat Baduy dan
Pengobatan Tradisional Berbasis Tanaman. Wacana, Vol. 11 No. 1 (April 2009): 8194.

Rahardi. F. 1996. Membuat Kebun Tanaman Obat. Jakarta: Puspa Sawara.

Sundawa, Tus Vicho Hartanto. 2016. Kajian Etnobotani Tumbuhan Obat oleh Masyarakat di Desa Gunung Masigit Kecamatan Cipatat Kabupaten Bandung Barat. Skripsi. Universitas Pasundan; http:// repository.unpas.ac.id/12650/, diakses 28 Maret 2017.

Suparni, dan Wulandari. 2012. Herbal Nusantara 1001 Ramuan Tradisional Asli Indonesia. Yogyakarta: Rapha Publishing.

Supriadi dkk. 2001. Tumbuhan obat Indonesia; Penggunaan dan khasiatnya. Jakarta: Pustaka Populer Obor.

Yani, Yayan Dewirezeki. 2016. Kajian Etnobotani Tanaman Obat oleh Masyarakat Desa Sumur Bandung Kecamatan Cipatat Kabupaten Bandung Barat. Skripsi. Universitas Pasundan. http://repository. unpas.ac.id/12401/. Diakses 28 Maret 2017

Zaman, M. Q. 2009. Etnobotani Tumbuhan Obat di Kabupaten Pamekasan-Madura Provinsi Jawa Timur. Pamekasan-Madura.Jawa Timur. Skripsi [Online]. UIN Maulana Malik Ibrahim Malang 